\title{
Best Practices and Emerging Trends in Recruitment and Selection
}

\section{Chungyalpa $\mathbf{W}^{*}$ and Karishma T}

Department of Management Studies, Sikkim Manipal Institute of Technology, Rangpo, Majitar, East Sikkim-737132, India

*Corresponding author: Chungyalpa W, Department of Management Studies, Sikkim Manipal Institute of Technology, Rangpo, Majitar, East Sikkim-737132, India, Tel: 03592-270294; E-mail: wgc.1976@gmail.com

Received date: February 08, 2016, Accepted date: March 10, 2016, Published date: March 15, 2016

Copyright: (c) 2016 Chungyalpa W, et al. This is an open-access article distributed under the terms of the Creative Commons Attribution License, which permits unrestricted use, distribution, and reproduction in any medium, provided the original author and source are credited.

\begin{abstract}
In today's hyper competitive business environment employees are a source of competitive advantage. It is absolutely critical for businesses to hire the right people, with the right skills, right knowledge, right attributes, at the right time, for the right job. The recruitment and selection process has become one of the key processes determining the success of an organization. This paper examines the recruitment and selection process and the latest trends concerning recruitment and selection. The paper consists of three sections. The first section defines the recruitment and selection process in its entirety. It examines and defines the various phases and sub phases comprising recruitment and selection. The second section explores best practices associated with recruitment and selection process. The final section lists the latest trends concerning recruitment and selection.
\end{abstract}

Keywords: Recruitment and selection; Recruitment and selection best practices; Recruitment and selection emerging trends

\section{Introduction}

Recruitment and selection process can easily be considered to be one of the most critical functions of an organization. As the business environment becomes more and more competitive, having the right people with the right skills for the right tasks becomes all the more critical. Indeed it can be a source of competitive advantage. Today organizations have moved from product focus to market focus to selling focus to customer focus to employee focus. It is common to hear organizations speak of their human resource as their biggest organizational asset. Indeed ultimately the capabilities of an organization falls upon the shoulders of its employees. An organizations is only as good as the capabilities of its employees. This paper starts by defining the recruitment and selection process followed by best practices in recruitment and selection. The final section examines the latest emerging trends concerning recruitment and selection.

\section{Overview of recruitment and selection process}

Recruitment and selection is a core function of the Human Resource department. It can be regarded as one of the most important functions performed by the HR department. Also commonly known as the staffing function, it involves the following phases:

- Job analysis

- Manpower planning

- Recruitment and selection

The following is a quick overview of the above phases.

\section{Job analysis}

All staffing requirements requires a detailed job analysis. Job analysis helps in determining the major characteristics and scope of a job. Job Analysis is a 'process to identify and determine in detail the particular job duties and requirements and the relative importance of these duties for a given job. Its fundamental purpose is to establish and document the job relatedness of employment procedures such as training, selection, compensation, and performance appraisal. Job analysis involves examining how tasks are performed, why they are performed, and when they are performed. It involves assessing jobs in certain context such as physical environment under which the job is performed, social environment, and financial conditions attached with the job. This refers to salaries, wages, bonuses, benefits etc. attached with the performance of the job [1].

\section{Man power planning}

Simply put man power planning refers to forecasting the number of workers required for the performance of a task or a job at some future point in time. Its main purpose is to 'ensure that it has the right number of people, and the right kind of people, at the right places, at the right time, doing things for which they are economically most useful [1].' Today Manpower planning methods are undergoing rapid changes and innovation [2]. Other than forecasting future employee needs, it must also be able to predict turnover in employees and make arrangements to fill the resulting gap. It must ensure no shortages or surplus in the employees.

\section{Recruitment and selection}

This is the phase where the actual prospective candidates are selected and hired by the company. It is a long and arduous process. Recruitment and selection can follow only after man power planning has ascertained the demand for new workers. Recruitment and selection process varies from company to company however the following are steps generally common to all companies.

Application form: Usually the first step in the selection process. Details are sought about the prospective candidates. Information is normally categorized into bio data, education, work experience, recreation etc. 
Page 2 of 5

Preliminary interview: These are brief interviews conducted to quickly ascertain suitability of candidates for the job. Its main aim is to eliminate those candidates that are unsuitable for the job. It is an important step as it ensures that the company invests time and effort only with prospective candidates that can perform the task.

Employment tests: These are sets of tests conducted to ascertain qualities and characteristics of potential candidates. Many different types of employment tests can be conducted. Each test is designed to measure a specific characteristic or capability of a prospective candidate. The main aim is to match an individual's physical, mental and temperamental capability with the requirements of the job.

Employment interview: This is the most common method for hiring new recruits and is widely used by all organizations. The main objective is to ascertain the suitability of the candidate. It provides opportunity to the organization to know the candidate better i.e. their motivation, ambition, outlook etc.

Physical examination: May or may not be part of selection process. In certain jobs like the military and police physical examination is mandatory due to the requirements of the job. However for most white collar jobs physical examination may not be required. Generally the candidates age is a reflection of his physical ability.
Final selection: Refers to the final selection of the candidate. At this stage selected candidates are issued employment letters. Initially all new hires are hired on probationary period. During this time candidates are assessed for their work ethic, dedication, motivation, honesty, integrity etc. The probationary period can last from 6 months to a year. Should the candidate successfully meet all the requirements, they will then be hired on a permanent basis.

Placement and induction: New hires are assigned office space. Induction may be conducted of new candidates. Induction may be a formal process of a informal process. The objectives of the induction process is to familiarize candidates with organizational procedures, rules and regulations. It is also aimed at boosting the confidence of the new recruits, instilling a sense of belonging, trust, and loyalty.

\section{Best Practices in Recruitment and Selection}

What are some of the best practices followed by the industry leaders? How are they able to hire the best and the brightest from a pool of candidates? Indeed, these are the million dollar questions. The following are compilation of best practices relating to recruitment and selection. The best practices are compiled according to the various phases of the recruitment and selection process (Table 1).

\begin{tabular}{|c|c|c|c|c|c|}
\hline S. No & Best Practice Description & $\begin{array}{l}\text { Australian Human Rights } \\
\text { Commission [3] }\end{array}$ & Manchester City Council [4] & Oracle [5] & Pobal [6] \\
\hline 1 & \multicolumn{5}{|l|}{ Job Analysis } \\
\hline (i) & $\begin{array}{l}\text { All job specifications must be up-to-date (job } \\
\text { analysis). The specifications must meet the } \\
\text { requirements of the job. }\end{array}$ & $x$ & & & $\mathrm{x}$ \\
\hline (ii) & $\begin{array}{l}\text { While assessing formal qualifications (academic, } \\
\text { trade, etc.,) ensure they are essential to the } \\
\text { performance of the job. Likewise while deciding } \\
\text { the length of experience, age requirements etc., } \\
\text { ensure they are 'essential and justifiable, for } \\
\text { performance of the job and not set arbitrarily or } \\
\text { based on stereotypes.' }\end{array}$ & $x$ & & $x$ & $\mathrm{x}$ \\
\hline (iii) & $\begin{array}{l}\text { Evaluate all job vacancies to ensure it is still } \\
\text { required to meet organizational needs. }\end{array}$ & & $x$ & & $X$ \\
\hline (iv) & $\begin{array}{l}\text { Job analysis must yield a well-defined 'person } \\
\text { specification.' A person specification is the 'basis } \\
\text { for assessment and decision-making. It sets } \\
\text { down the skills, behaviors, and underlying } \\
\text { competencies which enable a person to perform } \\
\text { that job successfully and in accordance with the } \\
\text { organization's values.' }\end{array}$ & & $x$ & $x$ & $\mathrm{x}$ \\
\hline 2 & \multicolumn{5}{|l|}{ Preliminary interview } \\
\hline (i) & $\begin{array}{l}\text { Short list candidates based on essential } \\
\text { qualifications first followed by desired } \\
\text { qualifications }\end{array}$ & $x$ & & $x$ & \\
\hline (ii) & $\begin{array}{l}\text { Document all decisions. Provide rationale for } \\
\text { each decision made. }\end{array}$ & $x$ & $\mathrm{x}$ & & $\mathrm{x}$ \\
\hline (iii) & $\begin{array}{l}\text { Candidate selection criteria must match the job } \\
\text { specifications. The selection criteria should focus } \\
\text { on skills, experiences, qualifications (knowledge) } \\
\text { essential to performance of the job. }\end{array}$ & $x$ & $\mathrm{x}$ & $x$ & $x$ \\
\hline (iv) & $\begin{array}{l}\text { Differentiate between essential criteria and } \\
\text { desirable criteria. Essential criteria are required } \\
\text { for the performance of the job. Without them, the }\end{array}$ & $x$ & & & \\
\hline
\end{tabular}


Citation: Chungyalpa W, Karishma T (2016) Best Practices and Emerging Trends in Recruitment and Selection. J Entrepren Organiz Manag 5: 173. doi:10.4172/2169-026X.1000173

Page 3 of 5

\begin{tabular}{|c|c|c|c|c|}
\hline & $\begin{array}{l}\text { worker will not be able to perform the job. } \\
\text { Desirable criteria are those that will aid in the } \\
\text { performance of the job. Having them is an added } \\
\text { benefit but they are not essential to the } \\
\text { performance of the job. }\end{array}$ & & & \\
\hline (v) & $\begin{array}{l}\text { Criteria must be specific. Avoid ambiguous and } \\
\text { vague criteria i.e. must possess good } \\
\text { communication skills. }\end{array}$ & $x$ & $x$ & $x$ \\
\hline (vi) & $\begin{array}{l}\text { Each criteria must have well defined assessment } \\
\text { method. }\end{array}$ & $x$ & & \\
\hline (vii) & $\begin{array}{l}\text { Prioritize all selection criteria according to } \\
\text { relevance and importance. }\end{array}$ & $x$ & & $x$ \\
\hline (viii) & $\begin{array}{l}\text { Base decision on all information; application } \\
\text { form, interview, referee's reports, tests, etc. }\end{array}$ & $x$ & & \\
\hline (ix) & $\begin{array}{l}\text { Be prepared to provide constructive feedback to } \\
\text { unsuccessful applicants on their performance } \\
\text { against the selection criteria. }\end{array}$ & $x$ & $x$ & \\
\hline$(x)$ & Keep a list of previous shortlists, reserve lists. & $x$ & $x$ & \\
\hline$(x i)$ & $\begin{array}{l}\text { Set up a recruitment panel responsible for the } \\
\text { overall R\&S process-from writing up the } \\
\text { advertisements, to specifying selection criteria } \\
\text { and assessment methods to making the final } \\
\text { selection. }\end{array}$ & & $x$ & $x$ \\
\hline (xii) & $\begin{array}{l}\text { 'No criteria should discriminate on the grounds of } \\
\text { race, caste, religious belief, disability, gender, } \\
\text { sexual orientation or age unless the criteria is } \\
\text { fundamental to the job, clearly justifiable and } \\
\text { meets the legal requirements of anti- } \\
\text { discrimination law.' }\end{array}$ & & $x$ & $x$ \\
\hline 3 & \multicolumn{4}{|l|}{ Employment tests } \\
\hline (i) & $\begin{array}{l}\text { Tests must match the essential requirements of } \\
\text { the job. }\end{array}$ & $x$ & & \\
\hline (ii) & $\begin{array}{l}\text { Tests must be void of any bias or indirect } \\
\text { discrimination }\end{array}$ & $x$ & & \\
\hline (iii) & $\begin{array}{l}\text { 'Think beyond just hard skills, knowledge and } \\
\text { experience. The right attitude may be one of the } \\
\text { most important factor in determining an } \\
\text { individual's success in a job.' }\end{array}$ & & $x$ & $x$ \\
\hline 4 & \multicolumn{4}{|l|}{ Interview } \\
\hline (i) & $\begin{array}{l}\text { 'Don't make assumptions about a person's ability } \\
\text { to do the job based on physical characteristics.' }\end{array}$ & $x$ & & \\
\hline (ii) & $\begin{array}{l}\text { 'Check if there is a need for any specific } \\
\text { arrangements (eg. Physical access, interpreters, } \\
\text { etc).' }\end{array}$ & $x$ & $x$ & \\
\hline (iii) & $\begin{array}{l}\text { Provide sufficient time for interviewee to } \\
\text { respond. Allow silence. }\end{array}$ & $x$ & $x$ & \\
\hline (iv) & $\begin{array}{l}\text { Ensure that all questions are tested and } \\
\text { prepared in advance. }\end{array}$ & $x$ & $x$ & $x$ \\
\hline (v) & $\begin{array}{l}\text { Keep detailed records of all questions and } \\
\text { answers. }\end{array}$ & $x$ & $x$ & $x$ \\
\hline (vi) & $\begin{array}{l}\text { Do not engage in invasive and irrelevant } \\
\text { questions i.e. will you get married soon? }\end{array}$ & $x$ & & \\
\hline 5 & \multicolumn{4}{|l|}{ Medical Examination } \\
\hline
\end{tabular}




\begin{tabular}{|c|c|c|c|c|c|}
\hline (i) & $\begin{array}{l}\text { All job specifications must be made available to } \\
\text { the medical examiner. }\end{array}$ & $x$ & & & \\
\hline (ii) & $\begin{array}{l}\text { 'Where there is concern about ability to perform } \\
\text { a job, the Medical Examiner should seek expert } \\
\text { advice and assessment from vocational } \\
\text { specialists.' }\end{array}$ & $x$ & & & \\
\hline 6 & \multicolumn{5}{|l|}{ Advertising } \\
\hline (i) & $\begin{array}{l}\text { Job descriptions must be clear, concise and } \\
\text { succinct. It should define the 'main purpose, } \\
\text { duties and expected achievements of the job.' It } \\
\text { must be in plain language and free of jargon. }\end{array}$ & & $x$ & $x$ & $x$ \\
\hline (ii) & $\begin{array}{l}\text { Job descriptions must be up to date and } \\
\text { 'properly aligned to service requirements.' }\end{array}$ & & $x$ & $x$ & $x$ \\
\hline 7 & \multicolumn{5}{|l|}{ Training } \\
\hline (i) & $\begin{array}{l}\text { All employees participating in recruitment and } \\
\text { selection must be trained, informed, and } \\
\text { knowledgeable about the R\&S process. }\end{array}$ & & $x$ & & \\
\hline 8 & \multicolumn{5}{|l|}{ Other ideas } \\
\hline (i) & $\begin{array}{l}\text { Exit questionnaire should be mandatory for all } \\
\text { leaving the organization. Exit interview should } \\
\text { take place if possible. }\end{array}$ & & $x$ & & \\
\hline
\end{tabular}

Table 1: Best practices in recruitment and selection self-compilation.

\section{Emerging Trends in Recruitment and Selection}

Currently the recruitment and selection approach is undergoing tremendous changes fueled by technological innovations and changes in strategic outlook. The following section examines some of the key trends impacting recruitment and selection process.

\section{Corporate talent network}

Corporate "talent networks" are online platform for promoting the company brand name. Its main objective is to attract new talent from a variety of sources which includes job candidates, fans, employees, alumni, partners, suppliers and even customers. It is very popular among the big firms and are increasingly being adopted by smaller and medium size firms as well. A talent network serves as a advertising and promotional hub for the company brand name. It is used to communicate job openings, career information, and other company information. The contents are usually tailored and targeted for each specific candidate.

\section{Building an end-to-end talent brand}

More and more companies today are focusing on building end to end talent brand. A talent brand refers to how the company is being perceived by its current employees, past employees and prospective employees. It is a method for communicating and showcasing the company corporate culture in real time. Companies today are developing strong talent brand strategy to reduce their cost per hire and lower turnover rates. A talent brand is something that is created via the joint efforts of the marketing department and the HR department [7].

\section{Use of applicant tracking software (ATS)}

One fast emerging trend is rapid adoption of Applicant Tracking Software (ATS). ATS are software designed specifically to meet the recruitment needs of a company. These software focus on managing the entire recruitment process, monitoring ad campaigns, and creating an excellent candidate experience. ATS can be used to post job openings, screen resumes, and generate interview requests to potential candidates by e-mail. Other features include individual applicant tracking, requisition tracking, automated resume ranking, customized input forms, pre-screening questions and response tracking, and multilingual capabilities [7].

\section{Develop mobile recruitment strategy}

Recent surveys indicate that increasingly large number of prospective candidates use mobile devices to access the internet and carry out personal tasks including job search. Hence, a growing trend among large firms is to create a mobile career site built specifically to meet the needs of the mobile device users. The aim is to use mobile recruitment to post jobs and create postings that can be easily shared on social media and readily responded to [8].

\section{Growing emphasis on using social networks}

Over the past few years, social networking sites such as LinkedIn and Facebook have rapidly gained prominence amongst internet users. These sites provide wealth of information on prospective candidates. Sites such as LinkedIn, and to an extent Facebook, provide specific recruitment related tools and analytic software to improve the recruitment process. Their aim is to help companies identify and locate the right talent for their company. Not surprisingly many firms have actively started using social networking sites for soliciting and 
Citation: Chungyalpa W, Karishma T (2016) Best Practices and Emerging Trends in Recruitment and Selection. J Entrepren Organiz Manag 5: 173. doi:10.4172/2169-026X.1000173

Page 5 of 5

recruiting new talents. The top preferred site is LinkedIn followed by Facebook and others [9].

\section{Increased focused on passive candidates}

Traditionally recruiters have focused on active candidates-those actively seeking new jobs. However, research has shown that vast majority of prospects (as high as 73\%) are passive candidates, that is they are not actively seeking jobs but are open to new opportunities and offers. This was found to be especially true in the case of social networking sites such as LinkedIn where vast majority of prospects were passive candidates. Hence, firms today are providing more and more emphasis on passive candidates. Indeed, much of the mentioned trends are aimed at attracting passive candidates [10].

\section{Conclusion}

Recruitment and selection remains one of the most important functions of the HR department. As competition increases between firms, selecting and recruiting the right and qualified talents become all the more important. Traditionally companies have largely relied upon prospective candidates to find the firm however today head hunting is a active function of the HR department. Firms not only need to head hunt but also must retain existing employees. The entire recruitment and selection strategy has changed and evolved to a new form where the onus lies on the firms to advertise, attract, and retain top talents. Internet based technologies and various other software and information systems have provided new capabilities like never before. There is a growing trend amongst firms to adopt and utilize these technical solutions. The future is bound to see an increased role of internet based solutions in recruitment and selection process.

\section{References}

1. Ramasamy T (2011) Principles of Management. Himalaya Publishing House Pvt ltd, Mumbai, India.

2. Psacharopoulos G (1991) From manpower planning to labour market analysis. Int'l Lab. Rev 130: 459.

3. Australian Human Rights Commission (2015) Good practice, good business: Eliminating discrimination and harassment from your workplace.

4. Manchester City Council (2015) Recruitment and Selection Guide.

5. Oracle (2013) Modern HR in the Cloud: Best Practices for Recruiting the Best Talents.

6. Pobal (2015) Guidelines on Best Practice in Recruitment and Selection.

7. Bersin J (2013) The 9 Hottest Trends in Corporate Recruiting.

8. Huhman HR (2014) 6 Recruitment trends you can't ignore in 2015.

9. Stewart R (2014) 5 Key Recruitment Trends for 2015.

10. Haak $\mathrm{T}$ (2015) 7 Trends in recruitment and selection. 